\title{
Birds of the Entella river (Genoa, Italy): a qualitative assessment of bird diversity in an urbanizing biotope, with implications for management and conservation
}

\author{
Andrea Simoncini ${ }^{1 *}$, Daniela Papi ${ }^{2}$, Enrico Ruggeri ${ }^{3}$
}

\begin{abstract}
This work presents the first assessment of the birds of the Entella river (Genoa, Liguria), a small wetland embedded in an urbanized matrix. Data were collected through standardized in situ censuses from April 2012 to June 2017 and integrated with historical and recent data from other verified sources. A total of 278 species are known from the site; 53 species $(19.06 \%)$ breed in the area, whereas $62(22.30 \%)$ species are vagrant and 81 species $(29.14 \%)$ are included in the Annex I of the Birds Directive (79/409/CEE). We determined the following indices: NP/P ratio $=1.48$, O.V.I. (Ornithological Value Index $)=20.53$. In-depth data are provided for vagrant species and for species of conservation concern, to prioritize conservation efforts. The results underline the importance of the Entella river as a local biodiversity hotspot and suggest a possible role of the area as a stepping stone in the regional ecological network. The study highlights a dichotomy between urbanization and high bird diversity in the area and acts as a first step towards its conservation and implementation.
\end{abstract}

Key words: bird conservation; urban ecology; stepping stone; Entella river.

Riassunto - Gli Uccelli del Fiume Entella (GE, Liguria): un'analisi qualitativa della diversità avifaunistica in un biotopo ad alto grado di urbanizzazione, con implicazioni gestionali e conservazionistiche.

Il presente lavoro costituisce la prima analisi qualitativa dell'avifauna del fiume Entella (Genova, Liguria), una zona umida di ridotta estensione compresa in una matrice urbanizzata. I dati sono stati raccolti tramite censimenti dell'ornitofauna condotti tra aprile 2012 e luglio 2017 e sono stati integrati da dati sia storici che recenti provenienti da altre fonti attendibili. Sono complessivamente note per l'area 278 specie, di cui $53(19.06 \%)$ nidificanti, $62(22.30 \%)$ accidentali ed 81 (29.14\%) incluse nell'Allegato I della Direttiva Uccelli (79/409/CEE). L'indice NP/P è risultato pari a 1.48 e l'I.V.O. a 20.53. Dati di maggiore dettaglio relativi a specie accidentali e di interesse conservazionistico vengono presentati al fine di fornire utili informazioni per interventi di miglioramento dell'area. I risultati documentano l'importanza del

${ }^{1}$ Corso Genova 32, 16043 Chiavari (GE), Italia.

${ }^{2}$ Via S. Giulia 8b, 16033 Lavagna (GE), Italia.

E-mail: danielapapi18@gmail.com

${ }^{3}$ Via S. Gatti 33, 16030 Castiglione Chiavarese (GE), Italia.

E-mail: ruggerienrico1958@gmail.com

* Corresponding author: simonciniandre@gmail.com

(C) 2018 Andrea Simoncini, Daniela Papi, Enrico Ruggeri

Received: 11 September 2018

Accepted for publication: 30 March 2019

Online publication: 18 June 2019 fiume Entella quale hotspot locale per la biodiversità e suggeriscono che l'area possa fungere da stepping stone nella rete ecologica regionale. Lo studio evidenzia il contrasto esistente tra l'alto tasso di urbanizzazione e la rilevante diversità ornitica, oltre a voler rappresentare un primo punto di appoggio per interventi di conservazione e ripristino dell'area.

Parole chiave: conservazione degli uccelli; ecologia urbana; stepping stone; fiume Entella.

\section{INTRODUCTION}

Urban development represents a major threat to the ecological uniqueness of local ecosystems (Blair, 2001; McKinney, 2006); habitats threatened by urbanization also show higher susceptibility to a host of other human impacts (McKinney, 2002). Urban sprawl generally causes habitat loss, the fragmentation of the original habitat into smaller natural patches (Whitney, 1985; Medley et al., 1995; Collins et al., 2000). Remnant patches show different levels of habitability to native species and different values of species richness (Whitney, 1985). Assessing biodiversity in these patches allows the identification of critical hotspots to preserve and restore, implementing local and regional ecological networks (Malcevschi et al., 1996; Possingham \& Wilson, 2005). The aim of this study is to provide a first assessment of bird diversity for a small Ligurian biotope, the Entella river, embedded in a sensibly altered urban matrix. Being surrounded by the growing cities of Chiavari and Lavagna (GE) the area has undergone profound changes in the past decades and is now highly prone to a variety of harmful impacts (Simoncini, 2017a, 2017b), including colonization by nonnative species of plants and animals - as typical of disturbed habitats (Luken, 1997; Marzluff, 2001) - and pollution. However, many studies - mostly fragmentary and outdated - suggested how the area seemed to retain a good biodiversity (Spanò, 1967; Spanò \& Podestà, 1981; Andreotti \& Casu, 1991; Lombardi \& Lajolo, 2009). This study targets such dichotomy - high bird diversity in the context of urbanization and habitat fragmentation - trying to get an improved understanding of it. It constitutes the first thorough assessment of bird diversity for the Entella river, considering both historical and most recent data. In-depth information for species of conservation concern and for vagrant ones is also provided to prioritize conservation efforts. Considerations are then made on the role 
of the Entella river in the regional ecological network, suggesting a possible line of interventions to be carried out in the area.

\section{STUDY AREA}

The Entella river (Genoa, Liguria) is the most important wetland in the Metropolitan City of Genoa, being one of the few remaining in the regional coastline which is highly urbanized and characterized by a strong predominance of rocky shores (Merlo, 1976). The river is placed 40 $\mathrm{km}$ East of Genoa in the Tigullio Gulf (central coordinates $\left.9^{\circ} 20^{\prime} 45.509^{\prime \prime} \mathrm{E}-44^{\circ} 19^{\prime} 13.695^{\prime \prime} \mathrm{N}\right)$. It belongs to the municipalities of Carasco, Cogorno, Chiavari and Lavagna. The area falls in the Ecoregional Subsection 2B1a of the Tyrrhenian Province (Blasi et al. 2014) and the dominant land cover is a loose urban matrix (Corine Land Cover 2012 code: 1.1.2). The Entella originates near Carasco (GE) where Sturla and Lavagna creeks meet. The river has a low gradient $(0-30 \%)$ and follows a NE-SW axis, flowing into the Tyrrhenian Sea after a $7 \mathrm{~km}$ run (Ambiente In Liguria, 2009). The bounds of the study site are marked in Fig. 1. The study area has an extension of 135 ha and includes - for an area of 78 ha - the SAC IT1332717 "Foce e medio corso del fiume Entella" established within the meaning of Directive 92/43/CEE "Habitat".

The study area is composed of 4 main habitat types:

i. the estuary, henceforth termed "mouth" (Fig. 2), comprises a mobile sandspit with few rushes (Juncus sp.).
In optimal conditions this habitat closely resembles a small Mediterranean salt marsh. The mouth isn't included in the SAC (Natura 2000 Network Viewer http://natura2000.eea.europa.eu/);

ii. the river (Fig. 3) presents a typical Mediterranean regime with summer-low and has a variable amount of gravel deposits depending on water height;

iii. the riparian zone (Fig. 4) is dominated by reedbeds of the invasive Arundo donax interspersed with residual clumps of native trees (Populus alba, Salix alba, Salix purpurea);

iv. the fields (Fig. 5), a mosaic of scattered trees, crops and hedges.

\section{MATERIALS AND METHODS \\ Data collecting}

A preliminary study of literature was done in order to set the basis for the subsequent work in the field. For many records (ranging from 1960 to 1985) we weren't able to retrieve a precise date. However, these data were taken into account considering the presence of photographic evidence for many of them and the experience of the observers. Data were collected from April 2012 to June 2017 through standardized censuses in the area, using binoculars $8 \times$ and a spotting scope $20-60 \times$. Whenever possible, rare species were documented both with acoustic and photographic record. Obtained data were integrated with observations from local birdwatchers. In

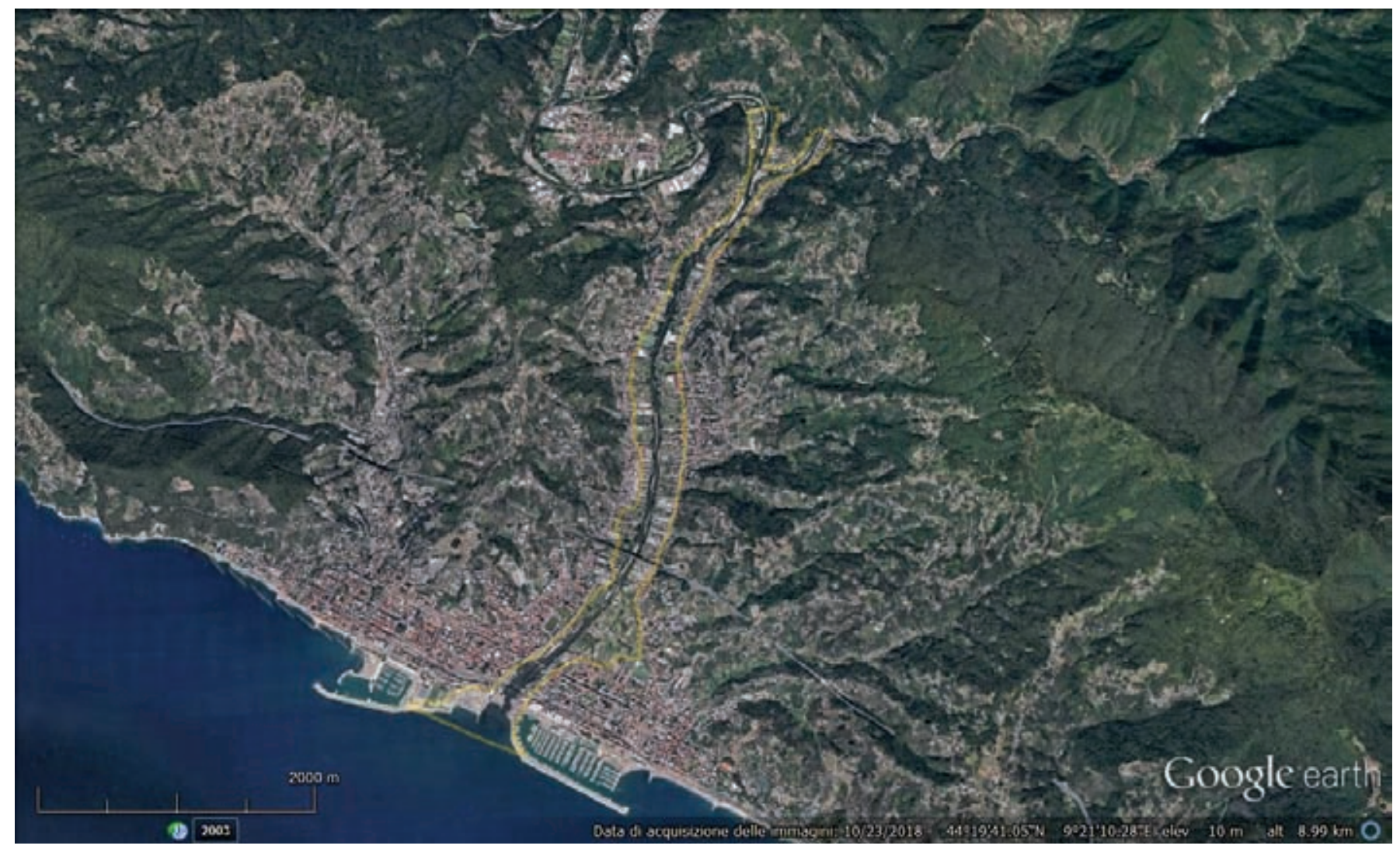

Fig. 1 - Cartographic framing of the study area (Entella river, GE). / Inquadramento cartografico dell'area di studio (Fiume Entella, GE). (From / Da Google earth). 


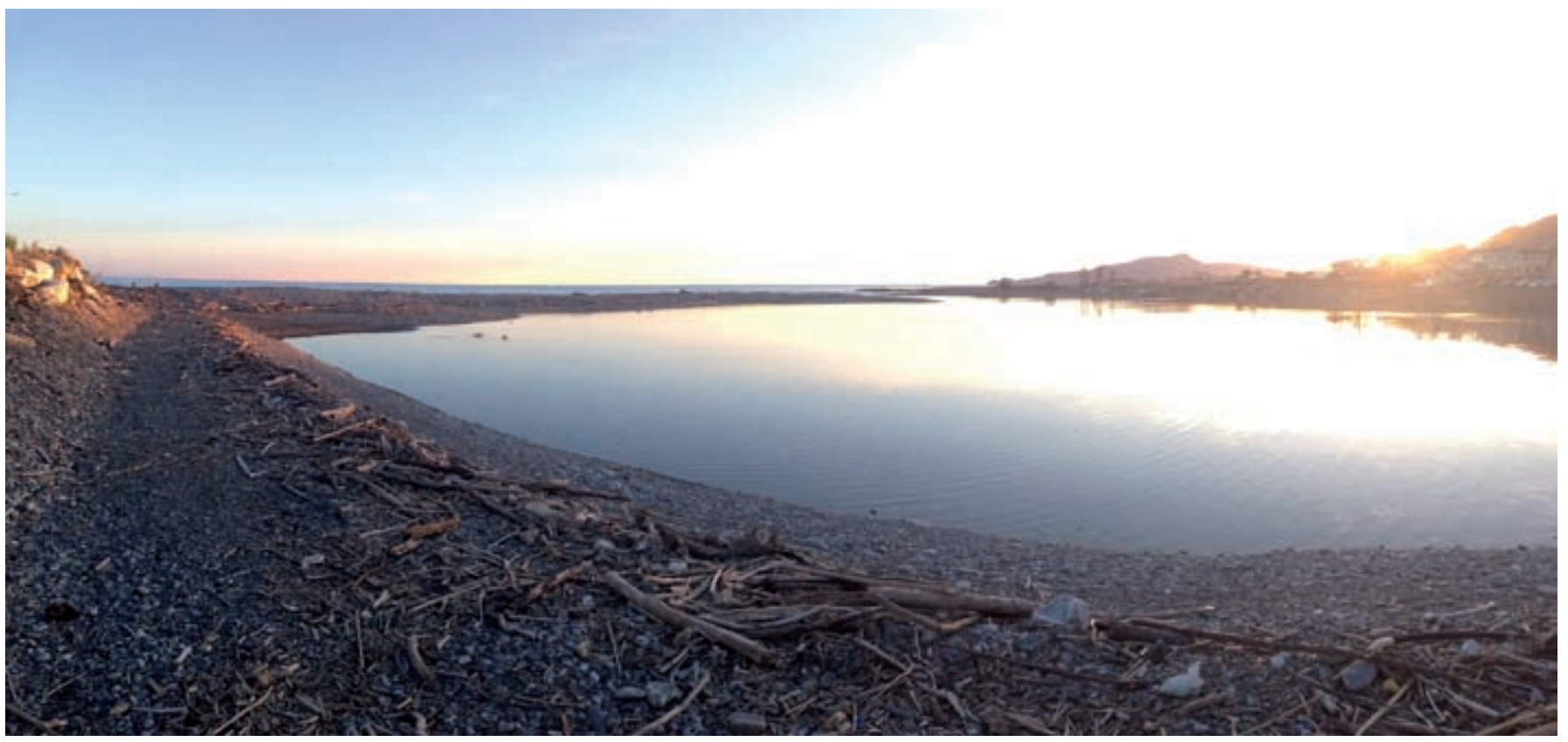

Fig. 2 - The mouth. / La foce. (Photo / Foto Andrea Simoncini)

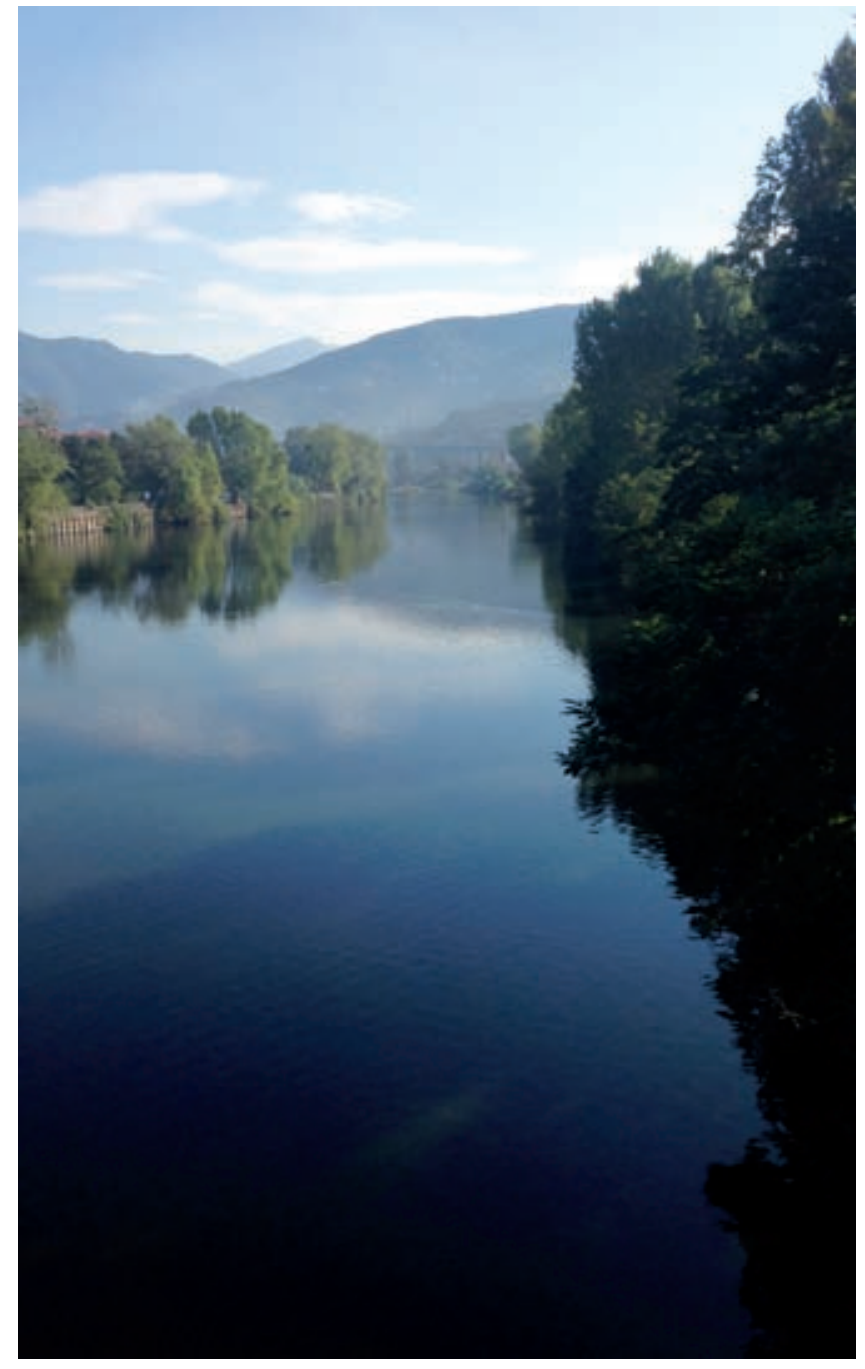

Fig. 3 - The river. / Il fiume. (Photo / Foto Andrea Simoncini).

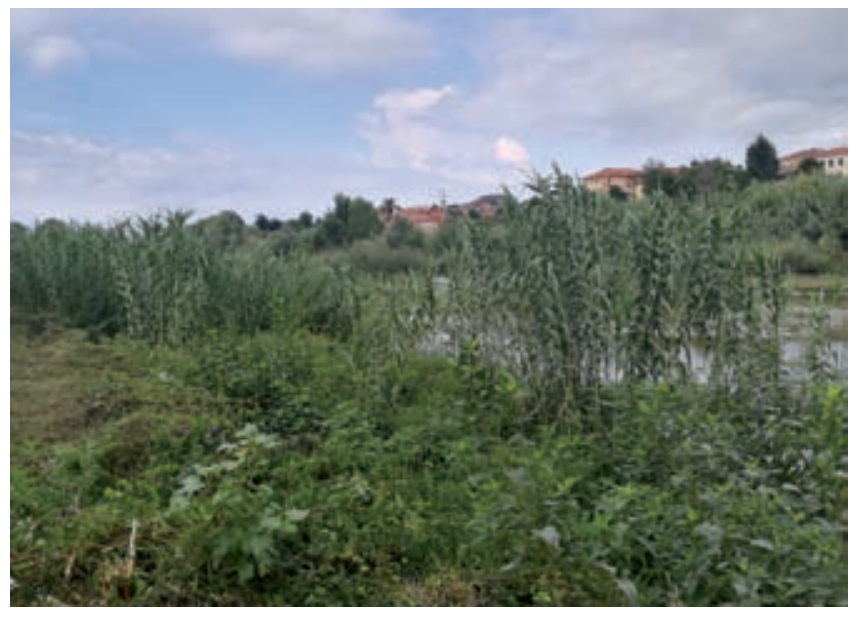

Fig. 4 - The riparian zone. / La zona rivierasca. (Photo / Foto Andrea Simoncini).

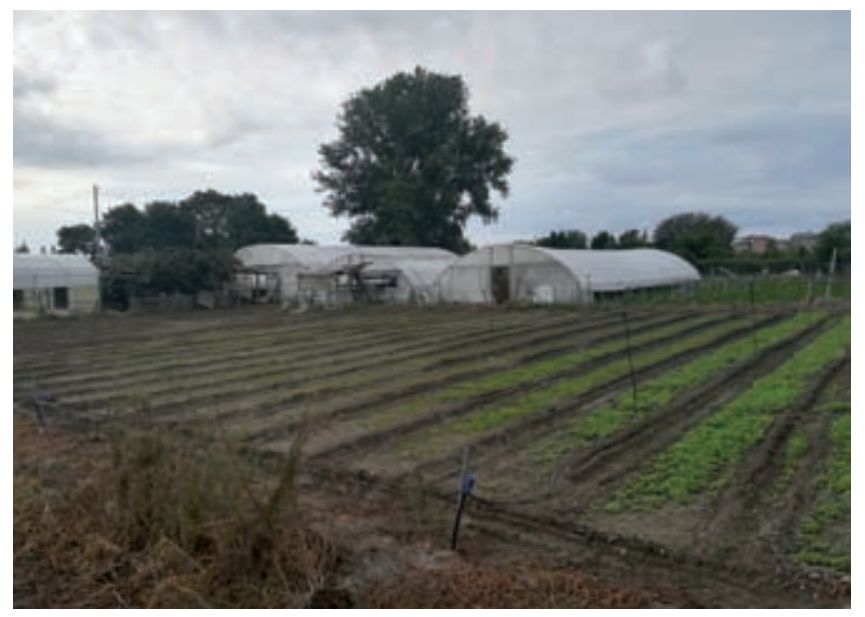

Fig. 5 - The fields. / I campi. (Photo / Foto Andrea Simoncini). 
this case, data would often be supported by photographic evidence. Finally, we examined two online ornithological platforms (www.liguriabirding.net, www.ornitho.it) and after a careful evaluation we selected the data of interest. In compliance with the rules of www.ornitho. it, for each observation a request of use was made to the data's owner. If a permission were not granted, the data would be removed from the dataset of the assessment. The date of the on-line search was also noted for each of these data.

\section{Index calculation}

To calculate the Ornithological Value Index (O.V.I.) of the study area, the following algorithm was applied (Massa et al., 2004; Termine et al., 2008):

$O V I=S_{\text {Tot }}\left[\left(S_{\text {Spec } 1} \times 1\right)+\left(S_{\text {Spec } 2} \times 0,75\right)+\left(S_{\text {Spec } 3} \times 0,50\right)+\right.$ $\left(S_{\text {non-Spec }} \times 0,25\right)+\left(S_{C R} \times 1\right)+\left(S_{E N} \times 0,75\right)+\left(S_{V U} \times 0,50\right)+$ $\left.\left(S_{L C}^{\text {non }} \times 0,25+S_{147}\right)\right] \times 100^{-1}$, where

- $S_{T o t}=$ total number of breeding bird species in the area;

- $S_{147}=$ number of breeding species included in the Annex I of the Birds Directive (09/147/CEE);

- $S_{\text {Spec } 1}, S_{\text {Spec } 2}, S_{\text {Spec } 3}, S_{\text {non-Spec }}=$ number of breeding species with SPEC values of 1, 2, 3 and non-SPEC, based on Birdlife International (2017);

- $S_{C R}, S_{E N} S_{V U} S_{L C}=$ number of breeding species included in each of the four ranks provided by the Red List of Italian breeding birds (Peronace et al., 2012).

\section{Taxonomy, nomenclature and abbreviations}

Regarding the scientific nomenclature and taxonomy adopted we followed the latest Italian check-list available (Brichetti \& Fracasso, 2015). For the English nomenclature we referred to the BOU check-list of the birds of Britain (British Ornithologists' Union, 2013), integrated by the IOC World Bird List when English vernacular names differed from international English names (Gill \& Donsker, 2017). To express phenology the following abbreviations have been used (adapted from Corso et al., 2012): A = vagrant: a species for which less than 5 records are known from the area (this is always followed by the number of records and their dating); $\mathrm{B}=$ breeding; $\mathrm{Mr}=$ regular migrant; $\mathrm{Mi}=$ irregular migrant (often due to lacking data or to variations in a species' abundance between past and recent years); SB = sedentary breeding: when the entire population breeding in the site is sedentary (as opposite to migratory breeding); $\mathrm{S}=$ summering; $\mathrm{SE}=$ sedentary (not breeding); $\mathrm{W}=$ wintering; $\mathrm{Wi}=$ irregular wintering; ? = doubtful data (the status is uncertain and not proved by sufficient documentation). Other abbreviations used are: $\mathrm{ad}=$ adult; det $=$ determination (if a bird has been identified by a different person from the original observer/photographer); $\mathrm{CY}=$ calendar year; ext = extinct (referred to historically breeding species); $\mathrm{f}=$ female; im $=$ immature; ind $=$ individual or individuals; juv $=$ juvenile; $\mathrm{m}=$ male; $\mathrm{ssp}=$ subspecies; $\mathrm{ud}=$ unknown date (of a proved record lacking the date). People names have been abbreviated as follows: $\mathrm{AA}=$ Alessandro Ardoino; $\mathrm{AI}=$
Alessandro Iacopi; AQ = Alessio Quaglierini; AS = Andrea Simoncini; $\mathrm{AV}=$ Annamaria Viotto; $\mathrm{DP}=$ Daniela Papi; EC = Enrico Chinchella; ECr = Ennio Critelli; EP $=$ Emilio Podestà; ER = Enrico Ruggeri; GB = Giuseppe Benini; GDA $=$ Giuseppe De Angelis; $\mathrm{GM}=$ Gabriella Motta; LB = Luca Bergamaschi; LBo = Luca Bonomelli; $\mathrm{LG}=$ Luigi Giunta; $\mathrm{MB}=$ Marcello Bottero; $\mathrm{MG}=$ Marco Guerrini; MS = Mauro Silveri; RO = Roberto Oneto; SD $=$ Silvio Davison; SDi $=$ Sandro Divano; $\mathrm{SP}=$ Stefano Podestà; $\mathrm{ST}=$ Stefano Tassano; $\mathrm{TB}=$ Tiberio Bertolone.

\section{RESULTS}

278 species (366 taxa) are currently known from the Entella river (see online Supplementary File); 53 (19.06\%) of them nest (50 with certainty - of which 5 extinct -, 2 probably, 1 possibly). The 4 most represented families are: Scolopacidae (26 species), Anatidae (24 species), Sylviidae (23 species) and Turdidae (17 species). The order Passeriformes makes up the $41.28 \%(\mathrm{~N}=112)$ of the total species number, with an NP/P ratio of 1.48 . Vagrant species account for the $22.30 \%$ of the total specific richness with 62 species. 81 species are included in the Annex I of the Birds Directive (79/409/CEE), 54 species are included in the Annex II of the same Directive, 52 breeding species are mentioned in the Red List of Italian breeding birds as LC (Least Concern) and 1 species (Passer italiae) is ranked in the same document as VU (Vulnerable). The O.V.I. (Ornithological Value Index) for breeding species equals to 20.53. The results highlight a great diversity of bird species in the area in spite of its high urbanization.

\section{SPECIES OF EUROPEAN CONSERVATION CONCERN}

Species of conservation concern (i.e. included in Annex I Dir. CEE) are described focusing on their status in the area. Vagrant species of conservation concern are also described here.

Anser albifrons (flavirostris?) Greater White-fronted Goose. Vagrant, with only a record known. A juv of this species was observed on 30 January 2017 (GDA pers. comm., det. DP, AS). Subspecies attribution needs further study. This was the $7^{\text {th }}$ record for the entire region, with the $6^{\text {th }}$ dating back to 1996 (Borgo et al., 2005, Spanò et al., 1998).

Cygnus cygnus Whooper Swan. One record is known: 1 ad observed on 7 May 2015 (TB pers. comm.). The lack of any ring to the legs and the quite elusive behavior indicate a probable wild origin of the ind (Fig. 6).

Aythya nyroca Ferruginous Duck. Irregularly observed on migration between March and June with single individuals ( 2 ind on 11 May 2015 - GB in www.liguriabirding. net consulted on 15 July 2017). A single observation in autumn: $1 \mathrm{ad} \mathrm{m}$ on 9 September 2016 (AS). This species may be underestimated for its attitude to migrate offshore (sometimes with flocks of Garganeys Anas querquedula and Shovelers Anas clypeata - AS).

Gavia stellata Red-throated Loon. The species is a regular winter visitor in nearby sites (e.g. Sanetti et al., 2009; Simoncini, 2014). Therefore, the small number of 


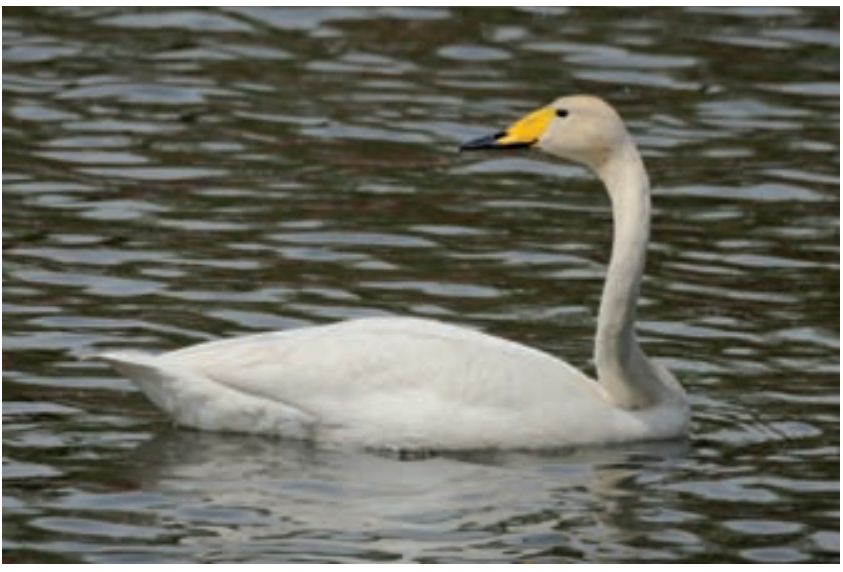

Fig. 6 - Whooper Swan Cygnus cygnus, 7 May 2015. / Cigno selvatico Cygnus cygnus, 7 maggio 2015. (Photo / Foto Andrea Simoncini).

observations in the area may not reflect its real abundance. Further studies are thus needed to assess the species' status. 2 known records from the Entella mouth:

- 1 ind on $18 / 12 / 2008$ (TB);

- 1 ind on 20/02/2016 (AA in www.liguriabirding.net consulted on 15 July 2017).

Gavia arctica Black-throated Loon. The presence of the species was mentioned in Andreotti \& Casu (1991). During our research, we obtained 3 further records:

-1 ind on $1 / 12 / 2010$ (DP);

- 2 ind on 13/12/2010 (DP);

- 1 ind on 6/12/2015 (AS, LBo).

Gavia immer Great Northern Loon. Vagrant species in Liguria with 10 obs. reported up to 2012 (Baghino et al., 2012). An historical and a recent record are known for the Entella mouth:

- 2 ind on December 1971 (EP);

- 1 ind on 1-3 January 2014 (AS, GB).

Calonectris diomedea Scopoli's Shearwater. Species observed mainly on spring migration (between mid-April and mid-June). Migration movements show a precise trend, being concentrated between the last decade of April and the first of May. A maximum number of 100 ind were observed on 11 May 2016, following a prevailing W-E migration route (AS). 2 summer sightings probably refer to ind breeding in high Tyrrhenian (3690-4715 pairs breed in Corsica, Sardinia and Tuscany; Brichetti \& Fracasso, 2003):

- 5 ind on 5/07/2009 (DP, ER, TB);

- 2 ind on 5/08/2016 (AS).

Puffinus yelkouan Yelkouan Shearwater. Regularly observed in variable numbers throughout the year, with the majority of individuals being counted during spring movements. Maximum concentrations are here reported:

- 300 ind on 11/05/2010 (GM, ECr, DP);

- 240 ind on 26/02/2017 (AS).

In summer few individuals have been reported (a maximum of 19 on 5 August 2016 - AS).

Podiceps auritus Horned Grebe. Vagrant, an ind observed on 30 Dicember 2007 (Bottero, 2008). An ind overwintered during 2015 in the nearby harbor of Lavagna, a few hundred meters from the study area (AS).
Phoenicopterus roseus Greater Flamingo. Three observations are known from the area:

- 1 juv on September 1988 (Andreotti \& Casu, 1991);

- 2 ind on 16/05/2013 migrating offshore W-E (TB, $\mathrm{GB})$;

- 3 juv on 5/10/15 (DP, ER, AS - Fig. 7).

Ciconia ciconia White Stork. Scarce and irregular migrant, few individuals were observed during spring migration (Mar-May). We obtained a single autumn data: 1 ind on 12 September 2015 observed feeding in agriculture fields (DP). A maximum of 6 ind was reported on 11 March 2010 (LG in www.liguriabirding.net consulted on 15 July 2017).

Platalea leucorodia Eurasian Spoonbill. More frequently observed during the last three years of the study, only in April with 1-2 ind/year, mainly juv. The species is ranked vagrant in the regional check-list (Baghino et al., 2012) but a recent increase in the observations both at local and regional level allows us to consider the species an irregular migrant at the Entella river.

Plegadis falcinellus Glossy Ibis. Regular migrant, even though quite scarce. More consistently observed during the last three years of the study (2015-2017), mainly in March and April. Maximum gatherings:

- 6 ind on 24/04/2016 (ST, AS);

- 5 ind on 7/05/2017 (AS, DP).

Botaurus stellaris Bittern. Only one recent sighting is known for the area (1 ind on 14 May 2017 - SP pers. comm.). The presence of the species is also reported in Lombardi \& Lajolo (2009).

Ixobrichus minutus Little Bittern. Regularly observed during spring migration. Earlier and later observations in the year are here reported:

- 1 ind on 29/03/2012 (SD, MS, GM in www.liguriabirding.net consulted on 15 July 2017);

- 1 ind on 9/06/2015 (DP, ER).

Nycticorax nycticorax Black-crowned Night Heron. Common migrant and scarce summering species. On average $70-90$ ind were observed each year throughout spring migration, with a maximum of 22 ind/day on 26 April 2016 (AS, DP, GB, EC).

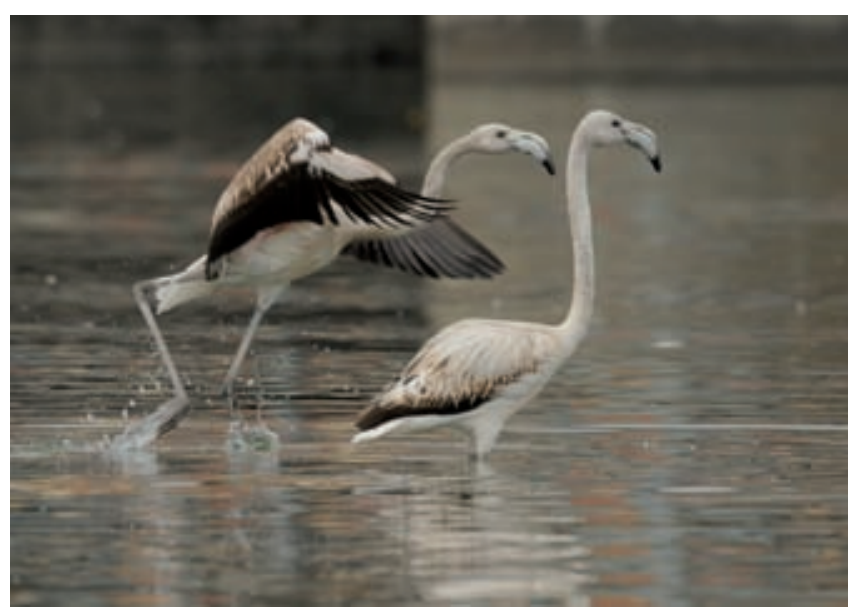

Fig. 7 - Greater Flamingo Phoenicopterus roseus, 5 October 2015. / Fenicottero rosa maggiore Phoenicopterus roseus, 5 ottobre 2015. (Photo / Foto Andrea Simoncini). 
Ardeola ralloides Squacco Heron. Scarce but regular migrant, 10-20 ind counted annually.

Ardea purpurea Purple Heron. Regular migrant, observed from March to June, with a marked peak on April. Often observed with Grey Herons in mixed flocks during migration periods. Rests mainly in river banks (rarely observed resting on rocks at the mouth - DP). Maximum gathering: 24 ind on 9 April 2011 (DP, ER, TB).

Casmerodius albus Great Egret. Commonly seen from March to the end of May. During the census period, 3-5 ind overwintered in the area (mainly near the Lavagna/ Sturla confluence) and 2 ind spent the summer in the same site (AS).

Egretta garzetta Little Egret. Observed throughout the entire year, scarcer during winter months (nov-feb). Maximum gathering observed: 36 ind on 15 August 2015 (AS).

Pelecanus onocrotalus White Pelican. Vagrant, with 1 record known for the Entella river: 1 ind from 9 to 11 October 2006 (Bertolone, 2007).

Phalacrocorax aristotelis European Shag. Mostly observed in summer and autumn in relationship to postbreeding movements. Often observed with single birds. Higher concentrations are here reported:

- 4 ind on 26/05/2016 (AS);

- 5 ind on 11/09/2016 (AS).

Pandion haliaetus Western Osprey. Vagrant, with four records known. An ind, shot on March 1963, is preserved in the Rocca ornithological collection. Many individuals were observed migrating on 20-24 April 1969 (EP). On September 2015 a migrant bird flew over the Entella mouth (RO pers. comm.). The last known observation refers to a migrating ind observed $3.5 \mathrm{~km}$ up the river on 15 April 2017 (AS). The scarce number of data reflects the status of the species at a regional level, with few individuals observed annually, and fits with the low ratio existing between (annually) migrating raptors over the area and migrating raptors (annually) counted at the major Ligurian bottlenecks (Baghino, 2013; Bottero, 2015, 2016).

Pernis apivorus European Honey-buzzard. Regular migrant in May, June, August and September. In the area, the species is mostly seen with scattered individuals and small gatherings. However, on 10-11 May 2016, with adverse meteorological conditions, namely 240 and 214 ind were observed migrating over the mouth (AS, DP, ER). Meteorological factors could have promoted such change in migratory route, as wind speed and general meteorological conditions affect migratory strategies in soaring raptors (Agostini et al., 2016; Panuccio et al., 2016).

Circaetus gallicus Short-toed Snake Eagle. Regular migrant on March-May, mainly observed 3-7 km far from the sea. Earlier observation: 1 ind on 5 March 2017 (AS). Later observation: 3 ind on 11 October 2015 (AS). The Short-toed Snake Eagle is also a scarce summering species in the site. Some individuals belonging to the 50-55 reproductive pairs in the Ligurian Apennines (Campora \& Cattaneo, 2006) exploit the Entella river as a hunting area. Indeed, 2 snake species (Hierophis viridiflavus, Elaphe quatuorlineata) inhabiting the area are included in the species' diet as main food sources (Petretti, 2008).
Clanga sp. Spotted Eagle sp. An individual of Spotted Eagle sp. was observed on 9 May 2016 (SP pers. comm., det. AS). Given the description, we could only identify the bird at a generic level (Clanga).

Aquila pennata Booted Eagle. Regular migrant, with peaks on March and October. Maximum gathering: 11 ind on 9 October 2016 (AS).

Aquila chrysaetos Golden Eagle. Vagrant, a datelacking observation is reported from the area (SP pers. comm.). This observation was probably linked to the dispersal of a juv from the breeding sites in the nearby Ligurian Appennines.

Circus aeruginosus Western Marsh Harrier. Observed on migration from March to May, often with single individuals. Rarely observed hunting in the fields (AS).

Circus cyaneus Hen Harrier. Some individuals of the species were observed migrating in April 1969 (EP). No recent observation is known.

Circus macrourus Pallid Harrier. An im in 2CY shot on March 1962 is currently preserved in the Rocca ornithological collection (Lavagna).

Circus pygargus Montagu's Harrier. Regular migrant up to 1990 (EP). There are no subsequent data reported from the area.

Milvus migrans Black Kite. Irregular migrant, observed from March to May. Seen hunting over the river and the adjacent agricultural fields (AS).

Tetrax tetrax Little Bustard. A single record of an individual shot in the area on 22 February 1984 (Toso, 1985).

Crex crex Corn Crake. Vagrant: an ind shot on 1970 (specimen preserved in the Rocca ornithological collection).

Porzana parva Little Crake. Irregular migrant, observed on April and May with single individuals. Further studies in the area may reveal a greater abundance of the species, always difficult to localize and quantify during in situ surveys.

Porzana porzana Spotted Crake. Vagrant, with 2 records known:

- 1 ind shot on 1965 (preserved in the Rocca ornithological collection);

- 1 ind on 19/04/2008 (TB).

Grus grus Common Crane. Regular migrant, observed migrating over the Entella mouth on March and November with a maximum concentration of 1050 ind on 3 March 2016 (AS, DP). A single data refers to individuals resting in the river bed: 2 ind on 24 November 2012 (MG in www.liguriabirding.net consulted on 15 July 2017).

Burhinus oedicnemus Eurasian Stone-curlew. Regular migrant with 10-20 ind observed annually, mainly in March. Maximum gathering known: 13 ind in the agricultural fields on 15 March 2011 (ER). Remarkable is the record of an individual on July 2016 (SP pers. comm.), as post-breeding migration of the species occurs mainly between October $17^{\text {th }}$ and November $20^{\text {th }}$ in Liguria (Bonifacino et al., 2015) and between the end of August and November (with a peak in September and October) in Italy (Meschini, 2010). The observation may thus be related to dispersal movements from breeding sites in NW Italy (Alessandria et al., 2015). 
Himantopus himantopus Black-winged Stilt. Regular migrant, mainly observed in spring (Mar-Jun, few observations in July and August) with an increasing overall number of ind/year. The positive trend of the species had already been highlighted by Spanò \& Podestà (1981). More commonly seen at the river mouth, the species has been observed up to $6 \mathrm{~km}$ far from the sea (AS).

Recurvirostra avosetta Pied Avocet. Regular migrant, annually observed with few individuals, mainly in spring (Mar-May). A single observation on autumn migration: 1 ind on 5 September 2008 (ER, DP). Maximum concentration: 16 ind on 24 March 2015 (DP).

Pluvialis apricaria European Golden Plover. Regular migrant, observed with 2-6 ind during early spring (FebApr) and 1-3 ind in autumn (Oct-Nov). The European Golden Plover might also be an irregular wintering species (e.g. many individuals were seen on December 1970 - EP). Maximum gathering: 7 ind on 7 March 2012 (ER, DP). The species was frequently observed feeding in the grassland 100 meters to the orographic right by the mouth (AS).

Charadrius alexandrinus Kentish Plover. Scarce but regular migrant, observed only at the mouth, often in mixed flocks with Common Ringed Plover Charadrius hiaticula, from March to May.

Gallinago media Great Snipe. A single observation without date is known for the area (Spanò \& Podestà, 1981).

Limosa lapponica Bar-tailed Godwit. Historically a rare species, the number of observations has been continuously increasing throughout the latest years. The species showed a precise migratory pattern with a peak in September (3-4 ind/year). A single spring observation: 1 ind on 11 May 2015 (DP).

Tringa glareola Wood Sandpiper. Regular and abundant migrant, observed throughout the study area both with single individuals and with gatherings (e.g. 20 ind seen on 20 April 2011 - TB, DP). Less common during post-breeding migration (Jul-Aug).

Xenus cinereus Terek Sandpiper. An individual observed on 10 May 2010 at the river mouth (MB, ER, DP) (Fig. 8).

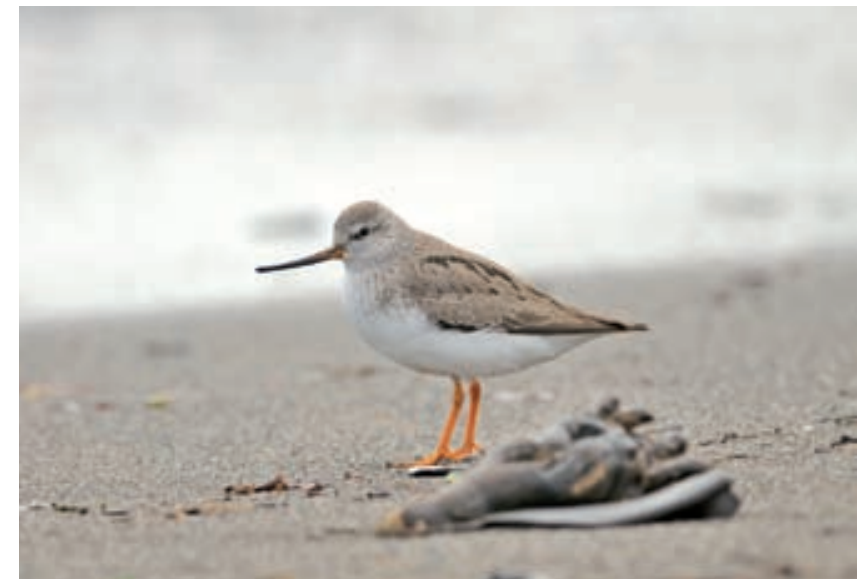

Fig. 8 - Terek Sandpiper Xenus cinereus, 10 May 2010. / Piro-piro del Terek Xenus cinereus, 10 maggio 2010. (Photo / Foto Daniela Papi).
Philomachus pugnax Ruff. Regular migrant, few individuals annually observed, mainly at the mouth, both during pre (Mar-May) and post (Jul-Oct) breeding migration.

Phalaropus lobatus Red-necked Phalarope. A juv was briefly sighted at the mouth on 7 October 2012 (DP). This accounted as the $2^{\text {nd }}$ regional observation ever (Baghino et al., 2012), with the $1^{\text {st }}$ dating back to 1975 (Spanò \& Truffi, 1987).

Glareola pratincola Collared Pratincole. Irregular migrant, seen almost annually with single individuals during April and May. On Spring 1975 an individual was observed feeding in the agricultural fields near to the river and subsequently captured and ringed (SP pers. comm.).

Croicocephalus genei Slender-billed Gull. Even though the species is considered vagrant in the regional checklist with 8 observations reported to 2012 (Baghino et al., 2012), the species is to be considered a regular migrant in the study area, following a recent local increase both in the number of observations and in the number of individuals involved (e.g. 12 ind on 2014, 24 ind on 2016 - AS, DP, ER).

Hydrocoleous minutus Little Gull. Irregular migrant (Mar-May). A single obs. in winter:

- 1 ind on 17/12/2011 (DP).

Larus audouinii Audouin's Gull. Vagrant with 4 known records from the area:

- 1 ind on 26/05/2014 (DP);

- 1 ind on 23/12/2014 (MG in www.ornitho.it consulted on 15 July 2017);

- 1 ind on 9/05/2017 (DP);

- 1 ind on 13/05/2017 (DP, EP).

Larus melanocephalus Mediterranean Gull. Regular migrant with conspicuous numbers (e.g. 440 ind on 6/11/2016 - AS). 100-200 ind overwinter in the area (nov/ dic-mar/apr). Few summer observations, mainly referred to im birds.

Gelochelidon nilotica Gull-billed Tern. Regular migrant with 4-10 ind/year (Apr-Jun). Mostly seen on active migration or fishing at open sea, sometimes observed resting in the river bed.

Sternula albifrons Little Tern. Regular migrant, observed with 3-8 ind/year from April to the beginning of June.

Hydroprogne caspia Caspian Tern. Regular migrant, more common from April to June (Fig. 9). Often observed at sea, sometimes the species has used the river as a stopover site (AS).

Sterna sandvicensis Sandwich Tern. Observed throughout the whole year, with a peak in the number of individuals in March and April, in relationship to migratory movements (a gathering of 34 ind observed on 5 March 2017 - AS).

Sterna hirundo Common Tern. Historically common (EP), only two recent observations are known:

-5 ind on $5 / 05 / 2016$ (AS);

- 3 ind on 1/06/2017 (DP).

The species may use a migratory path far from the Ligurian shoreline, as shown by the low number of individuals recorded in Liguria compared to the high concentrations observed at Bocca di Serchio, Pisa (AQ pers. comm.). 


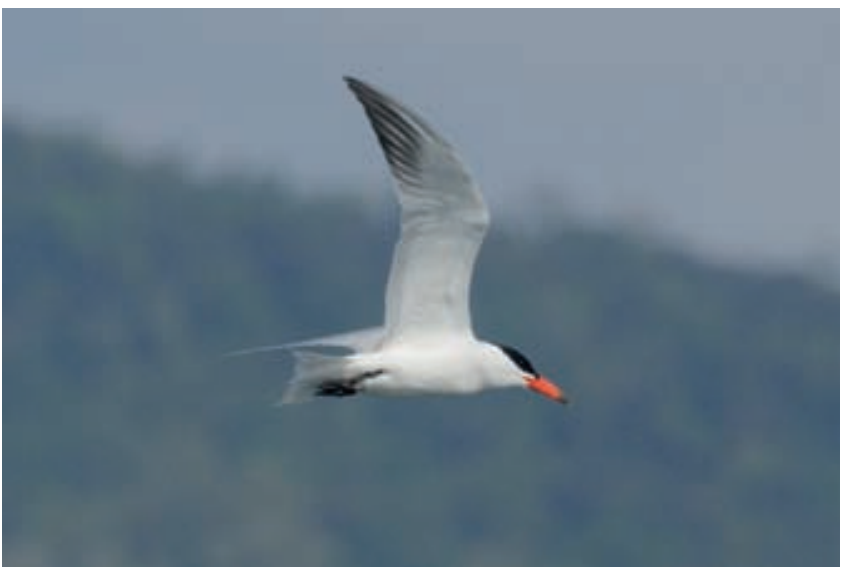

Fig. 9 - Caspian Tern Hydroprogne caspia, 5 May 2016. / Sterna maggiore Hydroprogne caspia, 5 maggio 2016. (Photo / Foto Andrea Simoncini).

Chlidonias hybrida Whiskered Tern. Regular but fairly-scarce migrant. 1-5 ind annually observed (Apr-May). One observation in summer (1 ind on 1 July 2009 - DP).

Chlidonias niger Black Tern. Few spring observations (Apr-May). Regular but scarce between July and September (post-breeding migration). An unusual observation in October: 1 ind on 15 October 2016 (GB in www.liguriabirding.net consulted on 15 July 2017).

Caprimulgus europaeus European Nightjar. The presence of the species as a migrant in the area is reported in Spanò \& Podestà (1981) and in Lombardi \& Lajolo (2009). No observations were reported after 1991. The difficulty to carry out night surveys in the area is probably at the origin of the lack of data.

Coracias garrulus European Roller. Regular migrant in May with 1-4 ind/year. Observed both on active migration and feeding on Orthoptera insects in agricultural fields (AS, DP, ER).

Alcedo atthis Common Kingfisher. Breeding sedentary species in the upper Entella river. In winter the species reaches higher densities, following the descent of several individuals from the Entella tributaries (AS).

Falco vespertinus Red-footed Falcon. Scarce, irregular migrant, more common in the past decades (Spanò $\&$ Podestà, 1981). Recently, one ind was observed at the mouth on 2 May 2015 (SD, in www.liguriabirding.net consulted on 15 July 2017).

Falco columbarius Merlin. Vagrant, with a single data from the Entella river of a bird shot on March 1968 (currently preserved in the Rocca ornithological collection).

Falco peregrinus Peregrine Falcon. Regularly observed with single individuals throughout the year. The individuals observed may originate from nearby breeding sites (e.g. Parco di Portofino, Rocche di Sant'Anna) (Sanetti et al., 2009, AS pers. obs.).

Lanius collurio Red-backed Shrike. Regular migrant in Apr-May and Sep-Oct. In past decades the species was a regular breeder in the area with a population of at least 10 pairs. The species is no longer breeding in the area since 2000 (SP pers. comm.). The disappearance of the species from the area fits with its general decrease at national and European levels and with the rarefaction of lowland breeding areas (Birdlife International, 2017; Brambilla et al., 2009; Mastronardi et al., 2016).

Lanius minor Lesser Grey Shrike. Irregular migrant, always observed with single individuals in the agricultural fields. Regularly seen in the past decades with 1-3 ind/ year (EP).

Lullula arborea Woodlark. Regular migrant and irregular wintering species.

Calandrella brachydactyla Greater Short-toed Lark. Regular migrant, observed in April and May with few individuals, more common in the past (EP). Mainly seen feeding in agricultural fields.

Melanocorypha calandra Calandra Lark. Vagrant with 3 records from the Entella river:

- 1 ind on April/May 1978 (Spanò \& Podestà, 1981);

- 1 ind ringed before 1981 (Spanò \& Podestà, 1981);

- 1 ind on 2/05/2015 (SD in www.liguriabirding.net consulted on 15 July 2017).

Acrocephalus melanopogon Moustached Warbler. Vagrant, an ind collected offshore at the Entella mouth on 17 June 1973 (EP).

Sylvia undata Dartford's Warbler. Vagrant, 1 ind (presumably a juv in dispersion from nearby breeding areas) seen on 26 October 2015 (AS).

Sylvia sarda Marmora's Warbler. Vagrant: 1 ind ringed on 13 April 1978 (Spanò \& Podestà, 1981).

Luscinia svecica Bluethroat. Scarce regular migrant, observed every year during the standardized censuses in March and April, both of svecica and cyanecula subspecies (with cyanecula being more common, Fig. 10). Data on past ringing activity in the area (1965-1983) showed an annual peak in catches between 20/03 and 10/04 (EP).

Ficedula albicollis Collared Flycatcher. Vagrant, with two observations known:

- 1 ind before 1979 (Spanò \& Podestà, 1981);

- 1 ind on 22/06/2015 (DP).

Anthus campestris Tawny Pipit. Observed annually in the fields with 15-30 individuals and maximum gatherings of $10-15$ ind (AS, DP, ER).

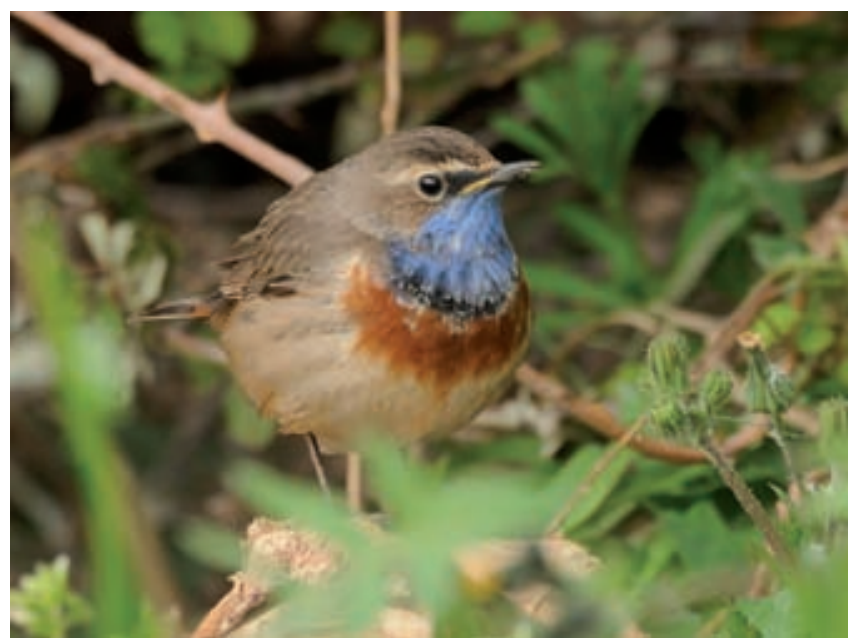

Fig. 10 - Bluethroat Luscinia svecica, ad m ssp. cyanecula, 28 March 2016. / Pettazzurro Luscinia svecica, ad m ssp. cyanecula, 28 marzo 2016. (Photo / Foto Andrea Simoncini). 


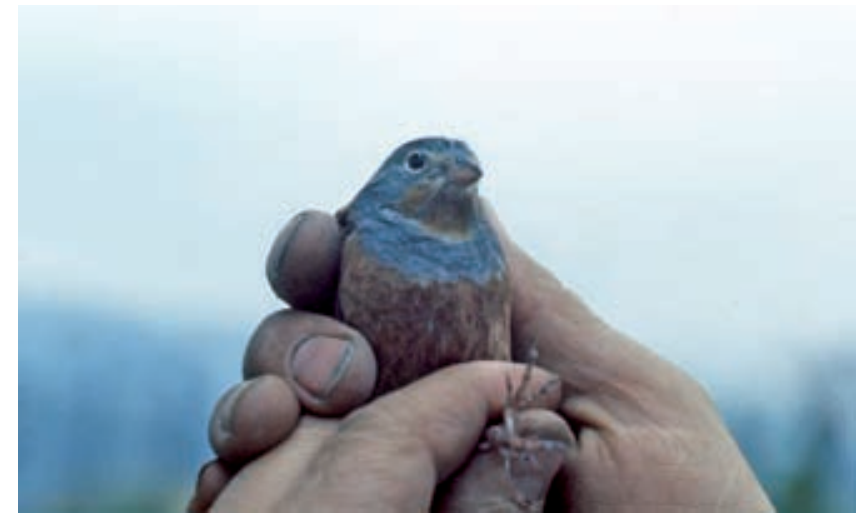

Fig. 11 - Cretzschmar's Bunting Emberiza caesia, ad m ringed at the end of April 1979. / Ortolano grigio Emberiza caesia, ad m inanellato alla fine di aprile 1979. (Photo / Foto Emilio Podestà).

Emberiza hortulana Ortolan Bunting. Regular migrant, the species showed a marked decline throughout the years reflecting the general decrease of the species (Birdlife International, 2017). The annual number of ind observed in the area dropped from $c 400$ in spring 1970 (EP) to the 3 ind in 2017 (AS).

Emberiza caesia Cretzschmar Bunting. A m ringed at the end of April 1979 (26 $6^{\text {th }}$ Italian record - Spanò, 1979) (Fig. 11).

\section{SYSTEMATIC LIST OF VAGRANT SPECIES}

Vagrant species (i.e. species with less than 5 known records from the area) are here described focusing on their occurrence in the area.

Anser fabalis Tundra/Taiga Bean Goose. A date lacking observation before 1990 (SP pers. comm.).

Aix galericulata Mandarin Duck. 2 ind (m, f) were briefly observed on 1 November 2009 (DP, TB).

Aythya marila Greater Scaup. A single observation before 1981 (EP).

Melanitta nigra Common Scoter. Six ind were seen at sea with a flock of Garganeys (DP) on 5 April 2017.

Mergus merganser Common Merganser. Two records known from the Entella river:

- 2 ind shot on 1963 (preserved in the Rocca ornithological collection);

- 1 ind on 18/03/2017 (DP, GB).

Thalassarche sp. Albatross sp. A single observation on 20 January 2008 refers probably to a Black-browed Albatross Thalassarche melanophris (Bottero, 2009). However, the Italian Ornithological Commission (COI) has homologated the record at a generic level (Thalassarche $s p$.) due to the impossibility to exclude the similar Atlantic Yellow-nosed Albatross Thalassarche chlororhynchos (Janni \& Fracasso, 2009).

Podiceps grisegena Red-necked Grebe. 2 observations known:

- 1 ind before 1981 (EP);

- 1 ind on 6/12/2016 (AS, AI).

Threskiornis aethiopicus Sacred Ibis. Two individuals rested for few hours in the river bed on 4 November 2015 (DP).
Egretta gularis Western Reef Heron. An ind ("dark morph") shot on 31 March 1972. The specimen is currently preserved in the Rocca ornithological collection.

Lymnocryptes minimus Jack Snipe. An observation before 1981 (EP). A recent record from the upper study area on 24 April 2016 (AV pers. comm., det. AS).

Numenius arquata Eurasian Curlew. A single observation, without date but previous to 1981, is known from the area (Lombardi \& Lajolo, 2009).

Limicola falcinellus Broad-billed Sandpiper. An ind of this species was ringed on 19 May 1965 (Spanò \& Podestà, 1981).

Larus marinus Great Black-backed Gull. An ind observed at the Entella mouth on the first days of April 1965 (EP).

Fratercula arctica Atlantic Puffin. Two ind shot on 1964 and 1965, preserved in the Rocca ornithological collection.

Apus pallidus Pallid Swift. 3 ind observed on 9 October 2016 (AS). The species is probably underestimated in the area, breeding with a few pairs $4 \mathrm{~km}$ away (LB pers. comm., AS pers. obs.).

Dendrocopos minor Lesser Spotted Woodpecker. An ind, shot on February 1968 beside the river in the municipality of Carasco, is currently preserved in the Rocca ornithological collection.

Lanius excubitor Great Grey Shrike. An ind shot on May 1964 (currently preserved in the Rocca ornithological collection).

Galerida cristata Crested Lark. A single data referring to a bird shot on February 1969 and currently preserved in the Rocca ornithological collection.

Eremophila alpestris Horned Lark. An ind shot on 1988 (SP pers. comm.).

Sylvia curruca Lesser Whitethroat. Only one historical observation lacking a date (SP pers. comm.).

Sturnus unicolor Spotless Starling. An observation of the species (without date) is known from the area (SP pers. comm.).

Turdus torquatus Ring Ouzel. 1 ind recorded on 15 October 1963 (EP). More recently, a migrant bird was observed on 31 March 2010 (DP).

Cercothricas galactotes Rufous-tailed Scrub Robin. An ind of the nominate subspecies ringed on 16 May 1983. It was the $6^{\text {th }}$ regional record and the $26^{\text {th }}$ known for the Italian peninsula (Spanò \& Truffi, 1984) (Fig. 12).

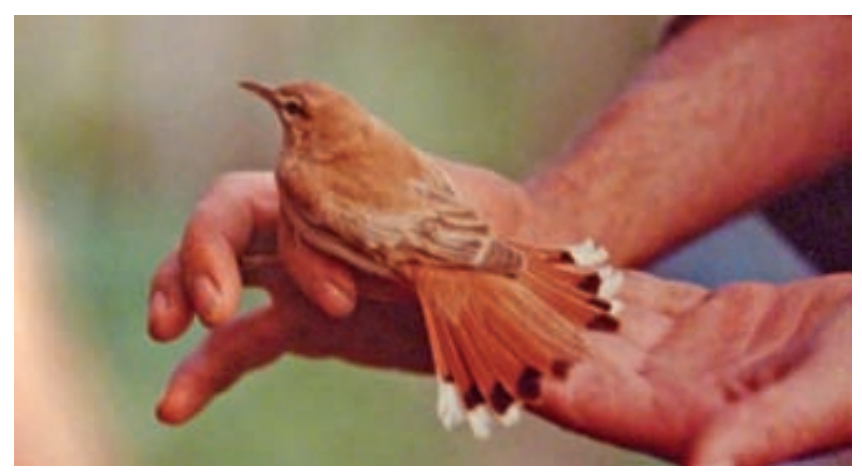

Fig. 12 - Rufous-tailed Scrub Robin Cercothricas galactotes galactotes ringed on 16 May 1983. / Usignolo d'Africa Cercothricas galactotes galactotes inanellato il 16 maggio 1983. (Photo / Foto Stefano Podestà). 


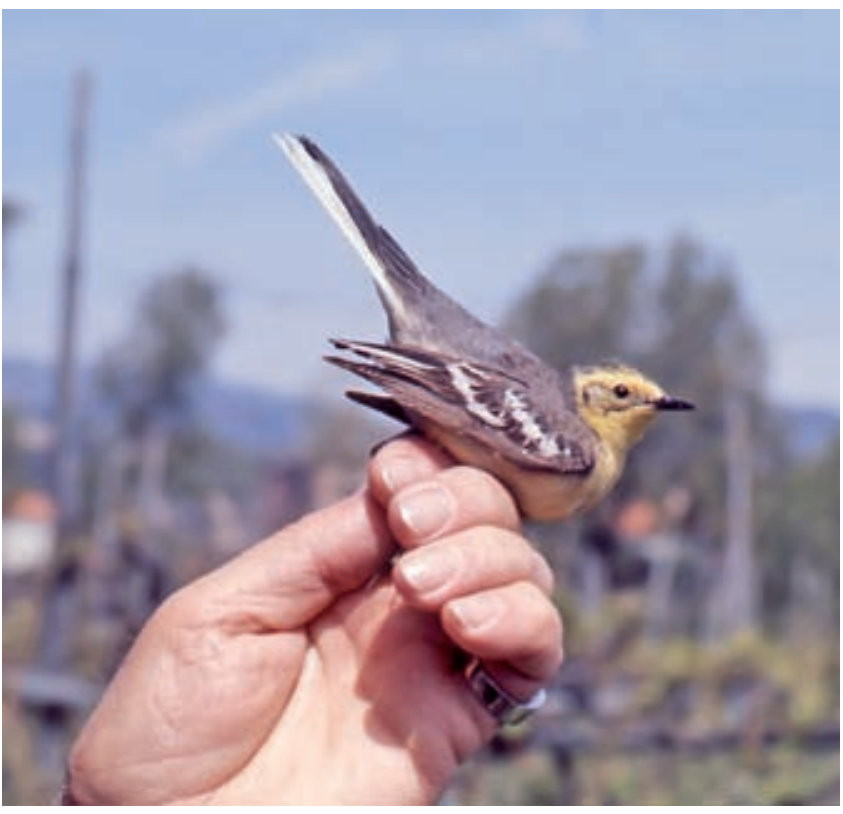

Fig. 13 - Citrine Wagtail Motacilla citreola, 2CY m ringed on 1 May 1976. / Cutrettola testagialla orientale Motacilla citreola, 2CY m inanellata il 1 maggio 1976. (Photo / Foto Emilio Podestà).

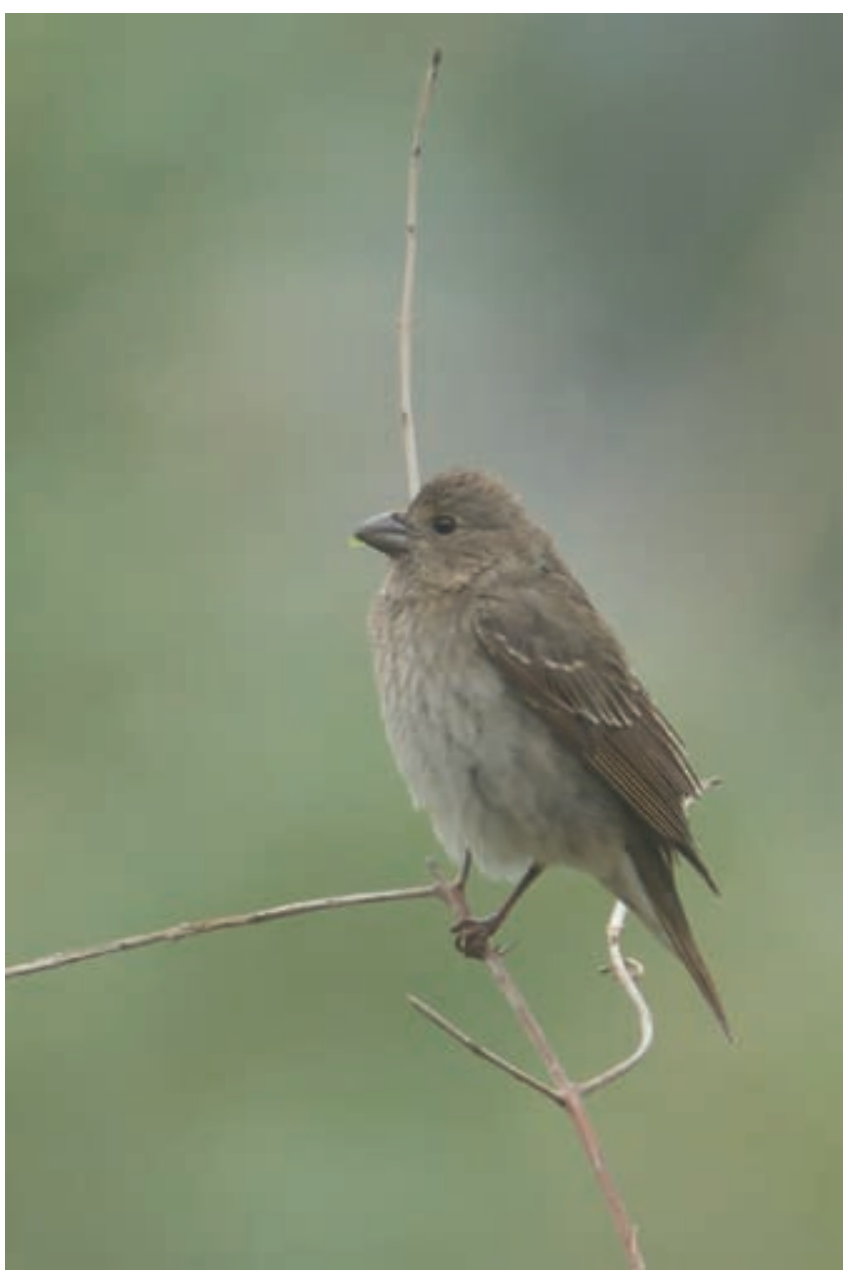

Fig. 14 - Common Rosefinch Carpodacus erythrinus, 27 April 2017. / Ciuffolotto scarlatto Carpodacus erythrinus, 27 aprile 2017. (Photo / Foto Daniela Papi).
Monticola saxatilis Common Rock Thrush. An ind captured in the agricultural fields on 11 April 1978 (EP).

Petronia petronia Rock Sparrow. An observation without date is reported from the area (EP).

Motacilla citreola Citrine Wagtail. A $2 \mathrm{CY}$ m ringed on 1 May 1976 (Spanò, 1979) (Fig. 13).

Pyrrhula pyrrhula Eurasian Bullfinch. One observation before 1980 (EP).

Carpodacus erythrinus Common Rosefinch. An ind was briefly observed in the agricultural fields on 27 April 2017 (DP). It was presumably a 2CY bird (Fig. 14). This was the $8^{\text {th }}$ Ligurian record, with the $7^{\text {th }}$ dated 1968.

Carduelis flammea Common Redpoll. An ind shot on February 1965 is preserved in the Rocca ornithological collection.

Loxia curvirostra Red Crossbill. In the Ligurian Apennines, the species exploits Larch plants as a food source (EP pers. comm.). In relationship to scarce food availability or to high reproductive success, Red Crossbills can show a high grade of dispersal, sometimes moving from uplands to lower areas (Berthold, 2003; Lucchi et al., 2016). Two invasions of the species, both in the month of July, are known for the Entella river in past decades (EP).

Carduelis citrinella Citril Finch. 1 ind observed on 14 March 2013 (DP).

Emberiza leucocephalos Pine Bunting. 1 ind shot on December 1965 (preserved in the Rocca ornithological collection).

Emberiza pusilla Little Bunting. 2 recent records from the area (Fig. 15):

- 1 ind on 25/11/2016 (DP);

- 1 ind on 15/12/2016 (DP, ER, AS).

These observations (referred to two distinct birds) were namely the $8^{\text {th }}$ and the $9^{\text {th }}$ in Liguria with the $7^{\text {th }}$ dated 1975 (Baghino et al., 2012).

Plectrophenax nivalis Snow Bunting. 1 ind shot on October 1965 is preserved in the Rocca ornithological collection. Recently, 1 ind was observed at the mouth from 12 to 14 November 2010 (DP, ER).

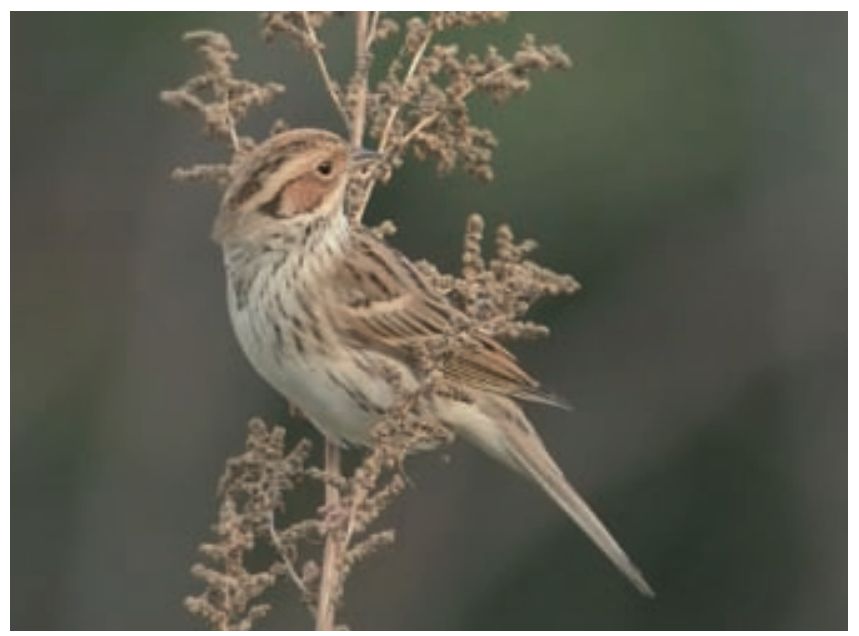

Fig. 15 - Little Bunting Emberiza pusilla, 15 December 2016. / Zigolo minore Emberiza pusilla, 15 dicembre 2016. (Photo / Foto Daniela Papi). 


\section{DISCUSSION}

The species reported from the area make up the $67.80 \%$ of the species known for Liguria $(\mathrm{N}=410$ - Baghino et al., 2012 ) and the $51.58 \%$ of the species recorded in Italy $(\mathrm{N}=539$ - Janni \& Fracasso, 2015). Therefore, the Entella river hosts a notable diversity of bird species, with some species being also particularly abundant at some stages of the annual life cycle (Simoncini, 2017b). This richness in species and in their abundance must be related to the richness in ecological niches offering a variety of food sources: the invertebrate-rich deposition bar at the mouth, the sheltered inland waters of the river, the hydrophytic vegetation and the adjacent crops. Moreover, the area is placed along the Tyrrhenian flyway, especially used by raptors and waders during migratory movements (Agostini et al., 2016; Simoncini, 2017a). The ornithological relevance of the area contrasts with its high urbanization. Retaining a high biodiversity in the process of habitat loss and urban expansion, the Entella river could serve as a stepping stone - a surrogate of a linear corridor in highly fragmented landscapes (Malcevschi et al., 1996; Lawton et al., 2010). Stepping stones are also nodes in an ecological network comprising many other components (Lawton et al., 2010; Harrison, 2016). They help maintaining landscape connectivity and ensuring functional connectivity, vital for the dispersal and migration of vertebrate taxa and especially birds (Taylor et al., 1993; Tischendorf \& Fahrig, 2000; Massa et al., 2004; Levey et al., 2005; Mitchell et al., 2013). The hypothesized role of the Entella river as a stepping stone is also supported from the low O.V.I. (20.53) for breeding species compared to the high species richness $(S=278)$. Following this hypothesis, an implementation of the area would help maintaing a coherent, resilient regional ecological network. The area also presents similarity with a restoration area, a partly degraded area where management aims at restoring a pristine habitat (Lawton et al., 2010; Harrison, 2016). Ecological restoration would also benefit the homeostatic, far out of equilibrium surrounding urban matrix, by providing energy inputs and absorbing waste products (Collins et al., 2000; McKinney, 2006). Part of the study area coincides with the SAC IT1332717 "Foce e medio corso del fiume Entella" but a relevant habitat type (the mouth) remains excluded and in the SAC the buffering of human impact has to date proved ineffective (pers. obs.; Simoncini, $2017 \mathrm{~b}$ ). In this area the reduced extent of buffer zones and the presence of anthropogenic barriers hinder the ability of some species to move between the various habitat types, increasing severance - the disconnection of habitats (Lawton et al., 2010; Harrison, 2016) -. Therefore, we suggest to carry out tailor-made interventions in the area targeting specific habitat types exploited by species of conservation concern. We hope data will prove useful for environmental surveys (e.g. Evaluations of Environmental Impact, Evaluations of Incidence) and for the drafting of management plans on the area.

\section{Acknowledgements}

The authors warmly thank Emilio Podestà and Marilena Rocca for providing data on historical records, past ringing activities in the area and several images.
They are very grateful to Daniele Baroni, who kindly revised the text. They also thank the fellow birders, ornithologists and photographers who provided observations: Alessandro Andreotti, Alessandro Ardoino, Daniele Baroni, Giuseppe Benini, Tiberio Bertolone, Luca Bonomelli, Marcello Bottero, Enrico Chinchella, Ennio Critelli, Giuseppe De Angelis, Silvio Davison, Sandro Divano, Luigi Giunta, Marco Guerrini, Guido Lombardi, Gabriella Motta, Roberto Oneto, Stefano Podestà, Mauro Silveri, Stefano Tassano. Special thanks go to Federica Bisanti (LIPU Tigullio) for teaching people in the area how to actively help protecting the Entella river. For always being on their mission for spreading ornithology and fascination for nature, they warmly thank Gabriella Motta and Ennio Critelli.

\section{REFERENCES}

Agostini N., Gustin M., von Hardenberg J. \& Panuccio M., 2016 Wind patterns affect migration flyways and flock size of a soaring bird over sea. Avian Biology Research, 9 (3): 159-166.

Ambiente in Liguria, Regione Liguria, 2009 - Piano di bacino stralcio sul bilancio idrico. Il bacino del Fiume Entella. Provincia di Genova, Area 06 (Difesa del Suolo, Opere ambientali e Piani di Bacino). $<$ http://www.pianidibacino.ambienteinliguria.it/GE/genova.html $>$ (retrieved on October 2017).

Alessandria G., Bogliani G., Brambilla M., Gola L., Mantovani S., Marotto P. \& Vigo E., 2015 - L'Occhione (Burhinus oedicnemus) in Italia Nord-Occidentale: evoluzione storica e situazione attuale. In: Occhione. Ricerca, monitoraggi, conservazione di una specie a rischio. Biondi M., Pietrelli L., Meschini A. \& Giunchi D. (eds). Edizioni Belvedere: 35-44.

Andreotti A. \& Casu L., 1991 - Guida naturalistica del fiume Entella. Provincia di Genova.

Baghino L., 2013 - Analisi dell'andamento delle popolazioni di Biancone Circaetus gallicus e Falco pecchiaiolo Pernis apivorus in migrazione nella ZPS “Beigua - Turchino" (GE). In: Atti Secondo Convegno Italiano Rapaci Diurni e Notturni. Treviso, 12-13 ottobre 2012. Ass. Faunisti Veneti. Mezzavilla F. \& Scarton F. (a cura di). Quaderni Faunistici, 3.

Baghino L., Borgo E., Bottero M., Galli L. \& Valfiorito R., 2012 Check-list degli uccelli di Liguria. Rivista Italiana di Ornitologia, 81 (1): $15-42$.

Berthold P., 2003 - La migrazione degli uccelli. Genetica, evoluzione, comportamento, ecologia. Bollati Boringhieri.

Bertolone T., 2007 - Pellicano comune Pelecanus onocrotalus. In: Annuario EBN Italia 2006. Ruggieri L. \& Sighele M. (ed.). Associazione EBN Italia.

Birdlife International, 2017 - European birds of conservation concern: populations, trends and national responsibilities. Birdlife Conservation.

Blair R.B., 2001 - Birds and butterflies along urban gradients in two ecoregions of the U.S. In: Biotic Homogenization. Lockwood J. L. \& McKinney M. L. (eds). Kluwer, 33-56.

Blasi C., Capotorti G., Copiz R., Guida D., Mollo B., Smiraglia D. \& Zavattero L., 2014 - Classification and mapping of the ecoregions of Italy. Plant Biosystems, 148 (6): 1255-1345.

Bonifacino M., Baroni D. \& Motta G., 2015 - L'Occhione (Burhinus oedicnemus) in Liguria. In: Occhione. Ricerca, monitoraggi, conservazione di una specie a rischio. Biondi M., Pietrelli L., Meschini A. \& Giunchi D. (a cura di). Edizioni Belvedere, 117119.

Borgo E., Galli L., Galuppo C., Maranini N. \& Spanò S. (a cura di). 2005 - Atlante ornitologico della Città di Genova (1996-2000). Bollettino dei Musei e degli Istituti Biologici dell'Università di Genova: $69-70$.

Bottero M., 2008 - Osservazione di Svasso cornuto Podiceps auritus alla foce del fiume Entella (Chiavari, GE). Il Biancone (Bollettino ROL), 3 . 
Bottero M., 2009 - Albatro dai sopraccigli neri Talassarche melanoprhis. In: Report Annuale Ligure: 2008. Baghino L. \& Bottero M. (eds.). Il Biancone (Bollettino ROL), 5.

Bottero M., 2015 - Dati finali sulla migrazione pre- e post-riproduttiva dei rapaci, anno 2014, in Liguria. Sito di Costa Fagaglia (Genova Pra'). Il Biancone (Bollettino ROL), 10.

Bottero M., 2016 - La migrazione pre-nuziale dei rapaci a Costa Fagaglia (GE). Anno 2016. Il Biancone (Bollettino ROL), 11.

Brambilla M., Casale F., Bergero V., Crovetto G.M., Falco R., Negri I., Siccardi I. \& Bogliani G., 2009 - GIS-models work well, but are not enough: Habitat preferences of Lanius collurio at multiple levels and conservation implications. Biological Conservation, 142: 2033-2042.

Brichetti P. \& Fracasso G., 2003 - Ornitologia Italiana vol. 1. Gaviidae - Falconidae. Alberto Perdisa Editore.

Brichetti P. \& Fracasso G., 2015 - Check-list degli uccelli italiani aggiornata al 2014. Rivista Italiana di Ornitologia, 85: 31-50.

British Ornithologists' Union (BOU), 2013 - The British List: a checklist of birds of Britain. $8^{\text {th }}$ ed. Ibis, 155: 635-676.

Campora M. \& Cattaneo G., 2006 - The Short-toed Eagle Circaëtus gallicus, in Italy. Rivista Italiana di Ornitologia, 76 (1): 3-44.

Collins J.P., Kinzig A., Grimm N.B., Fagan W.F., Hope D., Wu J. \& Borer E.T., 2000 - A new urban ecology. American Scientist, 88: 416-425.

Corso A., Penna V., Gustin M., Maiorano I. \& Ferrandes P., 2012 Annotated checklist of the birds from Pantelleria Island (Sicilian Channel, Italy): a summary of the most relevant data, with new species for the site and Italy. Biodiversity Journal, 3 (4): 407428.

Gill F. \& Donsker D. (eds.), 2017 - IOC World Bird List (v 7.2). <https:// www.worldbirdnames.org/DOI-7/master_ioc_list_v7.2.xlsx $>$.

Harrison L., 2016 - Connectivity and ecological networks. LI Technical Information Note.

Janni O. \& Fracasso G. (eds.), 2009 - Commissione Ornitologica Italiana (COI). Report 22. Avocetta, 33: 117-146.

Janni O. \& Fracasso G. (eds.), 2015 - Commissione Ornitologica Italiana (COI). Report 26. Avocetta, 39: 37-57.

Lawton J.H., Brotherton P.N.M., Brown V.K., Elphick C., Fitter A.H., Forshaw J., Haddow R.W., Hilborne S., Leafe R.N., Mace G.M., Southgate M.P., Sutherland W.J., Tew T.E., Varley J., \& Wynne G.R., 2010 - Making Space for Nature: a review of England's wildlife sites and ecological network. Report to Defra.

Levey D.J., Bolker B.M., Tewksbury J.J., Sargent S. \& Haddad N.M., 2005 - Effects of landscape corridors on seed dispersal by birds. Science, 309: 146-148.

Lombardi G. \& Lajolo A., 2009 - Nel respiro del fiume. Gammarò Edizioni.

Lucchi G., Baroni D. \& Valeri G., 2016 - Gli Uccelli di Pratorondanino. Il Biancone (Bollettino ROL), 11: 25-38.

Luken J. O., 1997 - Conservation in the context of non-indigenous species. In: Conservation in Highly Fragmented Landscapes. Schwarz M. W. (ed.). Chapman and Hall: 107-116.

Malcevschi S., Bisogni L. \& Gariboldi A., 1996 - Reti ecologiche ed interventi di miglioramento ambientale. Il Verde Editoriale.

Marzluff J. M., 2001 - Worldwide urbanization and its effects on birds. In: Avian Ecology in an Urbanizing World. Marzluff J.M., Bowman R. \& Donnelly R. (eds.). Kluwer: 19-47.

Massa B., Furia M., Bombace M. \& De Domenico R., 2004 - Proposta di gestione integrata delle aree protette dei Sicani. Naturalista siciliano, 28: 431-455.

Mastronardi D., Capasso S. \& Giustino S., 2016 - Misura del decremento di Lanius collurio in Campania in relazione all'altitudine. Uccelli d'Italia, 41: 5-13.

McKinney M.L., 2002 - Urbanization, Biodiversity, and Conservation. BioScience, 52: 883-890.

McKinney M.L., 2006 - Urbanization as a major cause of biotic homogenization. Biological Conservation, 127: 247-260.

Medley K. E., McDonnell M. J. \& Pickett S. T. A., 1995 - Forestlandscape structure along an urban-to-rural gradient. Professional Geographer, 47: 159-168.

Merlo C., 1976 - Le regioni d'Italia: 6. Liguria. Tipografia Sociale Torinese.
Meschini A., 2010 - L'Occhione. Tra i fiumi e le pietre. Edizioni Belvedere.

Mitchell M. E., Bennett E. \& Gonzalez A., 2013 - Linking landscape connectivity and ecosystem service provision: current knowledge and research gaps. Ecosystems, 16: 894-908.

Panuccio M., Barboutis C., Chiatante G., Evangelidis A. \& Agostini N., 2016 - Pushed by increasing air temperature and tailwind speed: weather selectivity of raptors migrating across the Aegean Sea. Ornis Fennica, 93: 159-171.

Peronace V., Cecere G.J., Gustin M. \& Rondinini C., 2012 - Lista Rossa 2011 degli Uccelli Nidificanti in Italia. Avocetta, 36: 11-58.

Petretti F., 2008 - L'Aquila dei Serpenti. Pandion Edizioni.

Possingham H.P. \& Wilson K.A., 2005 - Biodiversity: turning up the heat on hotspots. Nature, 436: 919-920.

Sanetti S., Motta G., Bonifacino M., Critelli E. \& Bassi E., 2009 - Monitoraggio annuale dell'avifauna nel Sito di Importanza Comunitaria "Parco di Portofino" (GE). In: Atti del XV Convegno Nazionale di Ornitologia. Sabaudia (LT), 14-18 ottobre 2009. Brunelli M., Battisti C., Bulgarini F., Cecere J.C., Fraticelli F., Gustin M., Sarocco S. \& Sorace S. (a cura di). Alula, XVI (1-2): 570-572.

Simoncini A., 2014 - Check-list degli uccelli del torrente Rupinaro (GE - Tigullio - Liguria). Uccelli d'Italia, 39: 121-128.

Simoncini A., 2017a - La migrazione dei limicoli alla Foce dell'Entella (GE) anno 2016. Il Biancone (Bollettino ROL), 12: 13-18.

Simoncini A., 2017b - Ciclo annuale della comunità ornitica del SIC IT1332717 "Foce e medio corso del Fiume Entella" (GE, Liguria). Uccelli d'Italia, 42: 85-90.

Spanò S., 1967 - Considerazioni su una raccolta ornitologica della Liguria orientale. Rivista Italiana di Ornitologia, 37: 314-335.

Spanò S., 1979 - Nuova cattura di Ortolano grigio in Italia. Rivista Italiana di Ornitologia, 49: 295-296.

Spanò S. \& Podestà E., 1981 - Quindici anni di inanellamenti a Chiavari e Lavagna (Osservatorio Ornitologico Ligure): risultati e osservazioni. Bollettino dei Musei e degli Istituti Biologici dell'Università di Genova, 48-49: 143-168.

Spanò S. \& Truffi G., 1984 - Nuova cattura di Usignolo d'Africa, Cercotrichas galactotes galactotes, in Liguria e rassegna delle presenze in Italia. Rivista Italiana di Ornitologia, 49: 295-296.

Spanò S. \& Truffi G., 1987 - Gli Uccelli della Liguria occidentale. Regione Liguria. Sagep.

Spanò S., Truffi G. \& Burlando B. (eds.)., 1998 - Atlante degli uccelli svernanti in Liguria. Regione Liguria.

Taylor P. D., Fahrig L., Heinen K. \& Merriam G., 1993 - Connectivity is a vital element of landscape structure. Oikos, 68: 571-573.

Termine R., Canale E. D., Ientile R., Cuti N., Di Grande S. C. \& Massa B., 2008 - Vertebrati della Riserva Naturale Speciale e Sito di Importanza Comunitaria Lago di Pergusa. Naturalista Siciliano, XXXII (1-2).

Tischendorf L. \& Fahrig L., 2000 - On the usage and measurement of landscape connectivity. Oikos, 90: 7-19.

Toso S., 1985 - Nuovi avvistamenti. Avocetta, 9 (1): 89-92.

Whitney G. G., 1985 - A quantitative analysis of the flora and plant communities of a representative midwestern U.S. town. Urban Ecology, 9: 143-160.

\section{SUPPORTING INFORMATION}

Additional Supporting Information may be found online for this article.

S1: Check-list of the birds of the Entella river (Chiavari, Lavagna GE) up to June 2017. / Lista completa della specie ornitiche del fiume Entella (Chiavari, Lavagna GE) aggiornata a giugno 2017. 